\title{
67. PALEOMAGNETISM OF LAMINATED SEDIMENTS FROM THE GUAYMAS BASIN, GULF OF CALIFORNIA, DEEP SEA DRILLING PROJECT SITE 4791
}

\author{
Robert Karlin and Shaul Levi, School of Oceanography, Oregon State University, Corvallis, Oregon
}

\section{INTRODUCTION}

Hole 479 in the Guaymas Basin of the Gulf of California $\left(27^{\circ} 50.8^{\prime} \mathrm{N}, 111^{\circ} 37.5^{\prime} \mathrm{W}\right)$ was drilled using the conventional DSDP rotary coring process, recovering $62 \%$ of the section. Although coring disturbance in the top 26 cores precluded paleomagnetic analysis, the remainder of the section (250-440 m sub-bottom) contained indurated, relatively undisturbed sediment with abundant, well-preserved laminae suitable for sampling. Since the age of the section and sedimentation rates were not well constrained, we examined the magnetostratigraphy of the lower part of the section to locate the Brunhes/Matuyama boundary or other magnetic markers.

\section{METHODS}

We took 47 paleomagnetic samples (43 laminated, 4 homogeneous) from relatively undisturbed portions of Cores 27 through 47 . Sampling and analytical methods were similar to those described by Karlin and Levi (this volume, Pt. 2). Remanence measurements of the $6.5-\mathrm{cm}^{3}$ samples were made on a cryogenic magnetometer. We subjected all samples to stepwise partial alternating field (AF) demagnetization to at least $100 \mathrm{Oe}$, which was near the limit of reliable measurement for most of the samples. Of the 47 samples, ten were rejected because of probable drilling or sampling disturbance (4), weak and inhomogeneous magnetization (4), or unstable directions during magnetic cleaning (2).

Based on changes in direction and intensity of magnetization during cleaning, we chose a 75 Oe-alternating field as the optimum demagnetization level for the remaining samples. Most samples, however, showed very little change in direction between the 50-, 75-, and 100 -Oe levels.

\section{RESULTS}

Variations in inclination and intensity with depth for the 75-Oe demagnetization level are summarized in Figures 1 and 2. For the 37 samples from 250 through 440 meters sub-bottom, the overall mean inclination after $75-\mathrm{Oe}$ AF demagnetization is $66.3 \pm 15.7^{\circ}$ or 67.2 $\pm 12.9^{\circ}$ if averaged by core. These values are about $20^{\circ}$ steeper than the expected geocentric axial dipole inclination $\left(46.6^{\circ}\right)$ at the sampling site and the mean NRM inclination at Site $480\left(46.4^{\circ}\right)$. Within-core variability at Site 479 , however, compares to that of Site 480 . All samples from Hole 479 are normally magnetized, and only one sample (at $370 \mathrm{~m}$ ) shows a low, stable inclination of $12.3^{\circ}$. We observed no systematic trends of inclination with depth.

At the 75-Oe AF level, intensities of magnetization are variable, ranging mostly from less than 1 to about 3

\footnotetext{
${ }^{1}$ Curray, J. R., Moore, D. G., et al., Init. Repts, DSDP, 64: Washington (U.S. Govt. Printing Office).
}

$\times 10^{-7} \mathrm{emu} / \mathrm{gm}$ (wet weight) or 1-3 $\times 10^{-6} \mathrm{emu}$ for typical 10-gram samples. Intensities of laminated samples below 365 meters are higher, by a factor of $\sim 1.4$, than intensities of samples found above this depth; however, the stability of remanence, as characterized by the $\mathrm{J}_{75} / \mathrm{J}_{\mathrm{NRM}}$ profile in Figure 2, shows no systematic changes with depth. Since, according to shipboard data, the 365-meter boundary coincides with a significant increase in silica dissolution and change in bulk density from 1.4 to $1.7 \mathrm{gm} / \mathrm{cm}^{3}$ at 360 to 370 meters, the higher intensities of samples below 365 meters probably reflect increased sediment consolidation.

Over the entire section, the sample-mean NRM intensity for the laminated sediments is $3.0 \pm 1.7 \times 10^{-7}$ $\mathrm{emu} / \mathrm{gm}$, or $2.8 \pm 1.1 \times 10^{-7} \mathrm{emu} / \mathrm{gm}$ if one sample from 321 meters is removed. When we compare the mean NRM intensity of laminated sediments from Hole $480\left(2.2 \pm 1.4 \times 10^{-7} \mathrm{emu} / \mathrm{gm}\right)$ to the laminated sediments from Hole 479, the latter sediments have a higher average intensity by about $20 \%$. Since the bulk density of Hole 480 sediments averages about 1.1 to $1.3 \mathrm{gm} / \mathrm{cm}^{3}$ versus 1.4 to $1.8 \mathrm{gm} / \mathrm{cm}^{3}$ from 250 to 440 meters in Hole 479 , according to shipboard data, most of the differences in intensity between the sites might also be attributable to increased mineral concentration associated with sediment consolidation.

\section{DISCUSSION}

The normally magnetized sediments from 250 through 440 meters (Cores 27-47) would seem to indicate a Brunhes age of less than 0.7 m.y. for all of the cored sediments in Hole 479, unless the 8-meter sand layer in Core 26 (231-239 m sub-bottom) represents a significant erosional unconformity. A Jaramillo age of 0.90 to 0.97 m.y. (Mankinen and Dalyrymple, 1979) for this 190 -meter section is unlikely, since the required sedimentation rates $(\sim 280 \mathrm{~cm} / \mathrm{ky})$ would be several times greater than rates obtained from varve counts (20-30 cm/ky), according to shipboard data.

Based on the silicoflagellate Mesocena elliptica extinction datum observed in Section 32,CC and its first occurrence in Section 39, CC, Schrader (this volume, Pt. 2) suggests that the sediments from 297 to 364 meters span a range in the Matuyama Reversed Epoch from about 0.7 to $0.9 \mathrm{~m} . \mathrm{y}$. Thus, the biostratigraphic and paleomagnetic stratigraphy appear to be at variance.

Both the NRM and "cleaned" inclinations throughout Hole 479 are much steeper than the inclination expected for a geocentric axial dipole. Furthermore, based on varve counts of several of the laminated samples, the period spanned by the 190 meters of sampled sedimen- 


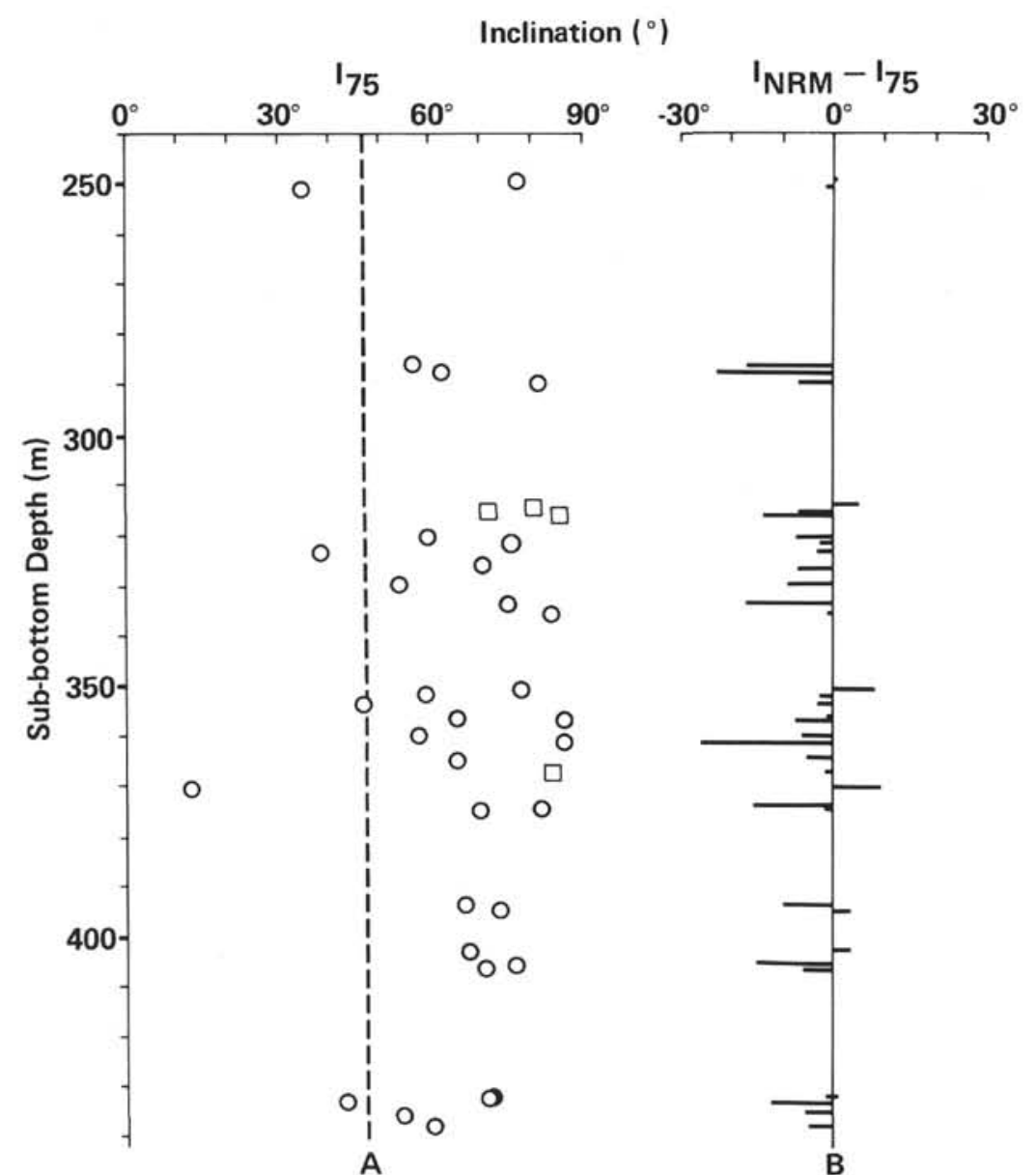

Figure 1. A. Paleomagnetic inclinations of 75-Oe-AF demagnetized samples from Site 479, Cores 27-47. Circles show laminated samples; squares show homogeneous samples. The dashed line at $46.6^{\circ}$ is the geocentric axial dipole inclination expected at the site. B. Inclination difference between NRM and 75-Oe demagnetization levels.

\section{Lithology}

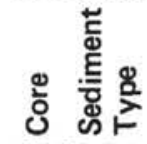

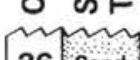

26 Sand

27 : 28

29 Dist.

\begin{tabular}{|l|l|}
\hline 30 & \\
\hline 31 & $H$ \\
\hline
\end{tabular}

31 L

32 .

\begin{tabular}{|l|l|}
\hline 33 & \\
\hline 34 & $\mathrm{H}$ \\
\hline
\end{tabular}

34 H

\begin{tabular}{l|l}
35 & $\mathrm{~L}$ \\
\cline { 2 - 2 } &
\end{tabular}

\begin{tabular}{l|l}
37 & Dist L. \\
\hline 37 & \\
\hline
\end{tabular}

38

\begin{tabular}{l|l}
39 & \\
\hline 40 &
\end{tabular}

40 -

41

\begin{tabular}{l|}
42 \\
\hline 43
\end{tabular}

\begin{tabular}{|l|l|}
\hline 43 & \\
\hline 44 & $\mathrm{~L}$
\end{tabular}

Dist.

\begin{tabular}{|l|l|}
\hline 45 & Dist. \\
\cline { 1 - 1 } 46 & \\
\hline 47 & \\
\hline
\end{tabular}

47 L

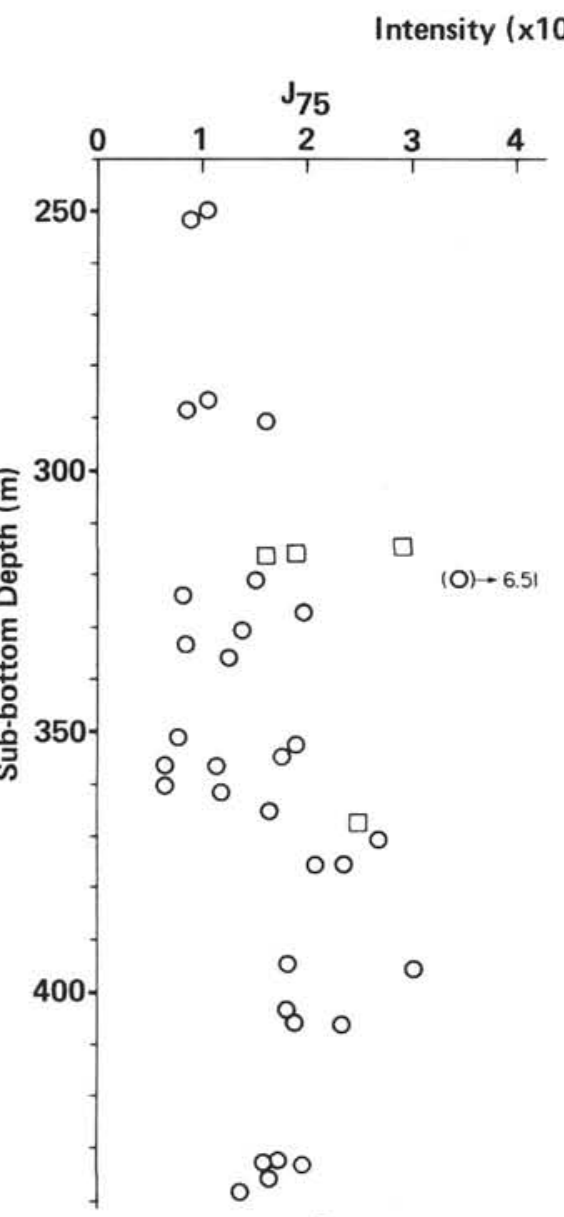

$\mathrm{emu} / \mathrm{g}$ )

$\mathrm{J}_{75} / \mathrm{J}_{\mathrm{NRM}}$

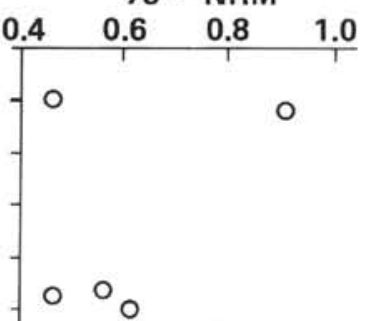

Figure 2. A. Summary of lithology by core at Site 479. L = laminated, $\mathrm{H}=$ homogeneous, Dist $=$ disturbed. Stippled areas are unrecovered sections. B. Magnetic intensity variations with depth for 75-Oe demagnetization level $\left(\times 10^{-7} \mathrm{emu} / \mathrm{gm}\right.$ wet weight). C. Ratio of magnetic intensities of 75-Oe demagnetization level to NRM. 
tary section must cover a minimum of $10^{5} \mathrm{y}$, Because the geomagnetic field during the last $\sim 5$ million years, averaged over periods $\geq 10^{4} \mathrm{y}$., has closely resembled a geocentric axial dipole (e.g., McElhinny and Merrill, 1975), the steep inclinations observed in Hole 479 may indicate that a secondary magnetization has been superimposed on the primary remanence.

Anomalously high inclinations can be caused by physical disruption of the sedimentary fabric, tectonic tilting of the strata, or sediment remagnetization. We would expect inclination errors induced by sedimentation and compaction to cause a shallowing rather than a steepening of the inclination. A visual inspection of the samples suggests that the parallel laminae are undisturbed and lie within $5^{\circ}$ of the horizontal. Tectonic rotation of initially southward-dipping beds by $\sim 20^{\circ}$ to a nearly horizontal position seems unlikely in the absence of additional seismic evidence. Thus, errors caused by physical disturbance, nonvertical drilling, or tectonic deformation of the strata are probably minor.

Nonetheless, overprinting of the NRM by a largely vertical, secondary magnetization might have occurred during drilling as a result of remanence imparted to the cutting head and linkages of the drilling assembly during periodic magnaflux testing for structural integrity. Such secondary magnetization of the sediments, probably an isothermal remanent magnetization (IRM), might explain the anomalously steep inclinations observed in Hole 479 and also those noted in some other Plio-Pleistocene sediments such as, for example, those from Sites 125 and 132 (Ryan and Flood, 1973). At Site 404, Hailwood (1979) found that steeply inclined components of secondary magnetization, possibly acquired during drilling, could be removed only by AF demagnetization levels above 200 Oe. At Hole 479, the weak magnetization of the sediments, except in a few cases, precluded cleaning above the 100-Oe level. Moreover, if secondary components are present, they might be more resistant to $\mathrm{AF}$ demagnetization than the primary remanence, since AF demagnetization led to a steepening of the inclination at $50 \mathrm{Oe}$, which then remained stable at the 75 - and $100-O e$ levels. Experiments in progress, using laboratory-induced anhysteretic and isothermal remanences, might determine whether overprinting is present, and, in particular, if it is likely that an originally reversely magnetized sedimentary section was completely remagnetized.

\section{CONCLUSIONS}

With the absence of identifiable magnetostratigraphic horizons, the age of the sediments at Site 479 cannot conclusively be determined from the present paleomagnetic study. The presence of normally magnetized sediments from 250 through 440 meters (Cores 27-47) would seem to indicate a Brunhes age for the entire stratigraphic section; but this hypothesis varies with available biostratigraphic data. Furthermore, because of the predominance of steep inclinations for most of the samples, the possibility of complete remagnetization of the sediments while drilling cannot be ruled out.

\section{ACKNOWLEDGMENTS}

We thank Hans Schrader for stimulating our interest in this project; Kerry Kelts and David Moore for supporting our shore-based participation; Kenneth Verosub and Dennis Kent for very prompt and helpful reviews; and Dennis Schultz for invaluable laboratory assistance. This research is supported by NSF grant OCE 7926440 .

\section{REFERENCES}

Hailwood, E. A., 1979. Paleomagnetism of Late Mesozoic to Holocene sediments from the Bay of Biscay and Rockall Plateau, drilled on IPOD Leg 48. In Montadert, L., Roberts, D. G., et al., Init. Repts. DSDP, 48: Washington (U.S. Govt. Printing Office), 305-339.

Mankinen, E. A., and G. B. Dalyrymple, 1979. Revised geomagnetic polarity timescale for the interval 0-5 My B.P. J. Geophys. Res., $84: 615-626$

McElhinny, M. W., and Merrill, R. T., 1975. Geomagnetic secular variation over the past 5 m.y. Rev. Geophys. Space Phys., 13: 687-707.

Ryan, W. B. F., and Flood, J. D., 1973. Preliminary paleomagnetic measurements on sediments from the Ionian (Site 125) and Tyrrhenian (Site 132) Basins of the Mediterranean Sea. In Ryan, W. B. F., Hsü, K. J., et al., Init. Repts. DSDP, 13, Pt. 2: Washington (U.S. Govt. Printing Office), 599-603. 